\title{
ÉTUDES RICEURIENNES
}

\section{Прощение как опыт возможного: подходы Х. Арендт и П. Рикёра}

\author{
Мария Сидорова \\ Аспирант школы философии факультета гуманитарных наук \\ Национального исследовательского университета «Высшая школа экономики» \\ Адрес: ул. Мясницкая, д. 20, г. Москва, Российская Федерация 101000 \\ E-mail: msi.8883@gmail.com
}

\begin{abstract}
Тема прощения объединяет различные философские интересы Х. Арендт и П. Рикёра. Оба мыслителя анализируют данный феномен в контексте авраамо-христианской традиции прощения, задаются вопросом о возможности прощения как явления совместной жизни. В статье обосновываются причины обращения Рикёра к концепции прощения Арендт. Выдвинута идея о том, что именно переосмысление понятия натальности Арендт лежит в основе утверждения Рикёром концепта «прощения для нас». Автор рассматривает как преемственность, так и разногласие подходов Рикёра и Арендт к проблеме прощения. Если Арендт осмысляет прощение в терминах поступка, то Рикёр анализирует его с позиции вопроса о самости. В теории Арендт прощение оказывается не типичным действием, а событием, разрывающим каузальную структуру совместности, неким исключением из публичного пространства, но необходимым для его существования. Рикёр же анализирует прощение как константу совместного бытия, как трудный акт, но постоянно возможный «инкогнито». Несмотря на подобные разногласия, понятие натальности Арендт становится для Рикёра решающей категорией при обосновании константы прощения. Вводя условие отделения агента от акта, он рассматривает натальность в качестве причины возможного обновления самости виновного. В статье высказана гипотеза, что именно обращение к Арендт помогает Рикёру сформулировать собственную концепцию «возможного» прощения, основанную на пересмотре принципов авраамической традиции и их рецепции в философии Деррида, и что благодаря отсылкам к теории Арендт в философии Рикёра место прощения как «опыта невозможного» занимает трудное, но возможное «инкогнито» прощения.
\end{abstract}

Ключевые слова: прощение, действие, память, забвение, плюральность, натальность, Поль Рикёр, Ханна Арендт

Поль Рикёр и Ханна Арендт принадлежат к разным направлениям философской мысли XX столетия. Имя Рикёра является знаковым для герменевтики и феноменологии, имя Арендт - для политической философии. Мыслители по-разному рассматривают одни и те же вопросы, в том числе и важный для современной философии вопрос о прощении.

Рикёр пишет о прощении в связи с проблемой дара. Несмотря на то, что сильное влияние на него оказали работы М. Мосса, Ж. Деррида, В. Янкелевича, а полемика с Деррида вообще послужила непосредственным поводом, приведшим

\footnotetext{
(c) Сидорова М. А., 2016

() Центр фундаментальной социологии, 2016
}

DOI: $10.17323 / 1728-192 \mathrm{X}-2016-2-192-207$ 
к выработке собственного подхода, все-таки ключевое значение, на наш взгляд, имеет для него переосмысление концепции прощения Арендт. Именно ее теория действия во многом определяет наиболее важный для Рикёра ракурс анализа феномена прощения: вопрос о «прощении для нас», т.е. утверждение возможности прощения в совместном бытии.

\section{Постановка проблемы прощения в философии П. Рикёра}

Обращение философов XX столетия к проблеме прощения предполагает пересмотр ее традиционного религиозного основания. Божественное прощение, отпущение греха уходят на задний план, на передний же выступает этика дара и обмена. Прощение рассматривается по аналогии с даром: акт освобождения виновного от бремени вины подобен дарению. Но кто, если не Бог, может совершить этот дар? Кто «автор» прощения? Исследование этого вопроса является важным этапом в развитии философии Рикёра ${ }^{1}$. В рамках данной статьи мы выносим за скобки те аспекты его социальной философии, которые рассмотрены, например, в сборнике эссе «Справедливое», где Рикёр обращается к категории прощения в связи с проблемами судебной практики и наказания преступления. Это важная тема, однако главное сказано философом при разработке герменевтической феноменологии самости, диалектики памяти и забвения. Ей он посвящает последние страницы книги «Память, история, забвение», разворачивая дискуссию с Деррида, Янкелевичем, Абелем, Н. Гартманом, а также с Арендт.

Концепция прощения формируется Рикёром путем переосмысления и синтеза идей указанных мыслителей. Так, он соглашается с Деррида в том, что язык прощения создан авраамо-христианской культурой, представляющей наследие общих подходов иудаизма, христианства и ислама к прощению (Рикёр, 2004: 647). Согласно основам этой культуры, прощение требует в качестве условия раскаяние, но в целом речь идет о безусловном акте (даре), который распространяется и на область непростительного ${ }^{2}$.

«Прощение есть» (Рикёр, 2004: 645) - такой авраамо-христианский ответ на невозможность прощения становится отправным тезисом для умозаключений Рикёра. Философ осмысляет «есть» как «оность», называя источником прощения саму субъектность. Однако в отличие от авраамической традиции он не отождествляет её с абсолютным субъектом или с божественным образом, а рассматривает как персонификацию. «У истоков „оности“ [прощения], вероятно, всё-таки нахо-

1. Проблематика причастности П. Рикёра к философии дара раскрыта в работах А. В. Ямпольской. В данной статье мы не предпринимаем ее дополнительного освещения, которое потребовало бы от нас сопоставления концепции прощения Рикёра не с идеями Арендт, а с мыслью Деррида.

2. Авраамо-христианская традиция прощения представлена в общей памяти религий Священного Писания (иудаизма, христианства, ислама). Она основана на принципе безусловности прощения со стороны божественной субстанции. Данное понятие Деррида применяет для обоснования противоречий безусловного и условного дара прощения. Этот термин использует и Рикёр, указывая на истоки становления проблемы прощения. 
дится личность в том смысле, что она является первопричиной персонализации» (Рикёр, 2004: 645).

На «высоту» прощения Рикёр помещает не абстрактного субъекта, а самость (ipseite) - один из основных предметов его герменевтической феноменологии. С позиции философии самости проблема прощения ставится им как вопрос и о субъекте-авторе прощения, и о самости виновного. И в прощаемых, и в прощающих он предлагает видеть личностей, которым свойственны признаки самости.

Данные признаки описаны Рикёром в работе «Я сам как другой» с помощью четырёх вопросов о «кто»: «кто говорит? кто действует? кто рассказывает о себе? кто является субъектом вменения?» (Ricoeur, 1990: 28). Ответы на них формируют образ «человека могущего» (homme capable).

Быть homme capable означает реализовывать способности говорить, действовать, рассказывать о себе и нести ответственность за поступки. Ответственность же предполагает осознание вины ${ }^{3}$, что рассматривается Рикёром в качестве предпосылки для прощения виновного. Разговор о прощении ведётся им в контексте вопроса об ответственности за действия (Рикёр, 2004: 637). Тем самым, на наш взгляд, прощение включается в ряд способностей человека могущего. В герменевтической феноменологии Рикёра прощение предстаёт как акт признания виновного в качестве человека могущего. Условием же подобного акта со стороны тех, кто прощает, является признание виновным ответственности за собственные поступки.

Проблема прощения в философии Рикёра оказывается загадкой о homme capable (Рикёр, 2004: 633). Она ставится философом во многом в ответ на рецепцию авраамо-христианского подхода в концепции прощения Деррида. Обнаруживая противоречие между безусловностью прощения и требованием раскаяния в иудео-христианской традиции ${ }^{4}$, Деррида определяет прощение как безусловный акт, независимый от просьбы, однако приходит к выводу о невозможности чисто20 прощения. С его точки зрения, любой безусловный дар прощения предполагает экономическую логику дара-обмена (Derrida, 1991: 36). Деррида трактует прощение как чрезвычайное и исключительное явление, как опьт невозможного (Derrida, 2005: 32). Рикёр же задаётся вопросом о возможностях применения «гимна» прощения авраамической традиции в человеческом мире, он спрашивает: «существует ли прощение для нас?» (Рикёр, 2004: 648).

3. Рикёр не всегда последователен в рассуждениях о зависимости вины и ответственности. Так, в эпилоге сборника эссе «Справедливое» он описывает ситуацию «ответственен, но не виновен», возможную при подмене политической вины уголовной. На примере суда над французскими политиками о заражении крови (1999 год) он высказывает идею о необходимости разделения политической и уголовной вины, призывая к созданию собственного института наказания в сфере политики (Рикёр, 2005: 273-274).

4. «Деррида тщательно деконструирует двойственность условности и безусловности, присущую иудео-христианской традиции, показывая, что высший расчет встроен в саму историю Авраамова жертвоприношения: пускай поступок Авраама был бескорыстным, пускай он был абсолютной жертвой; тем не менее за ним следует божественное вознаграждение, вписывающее его постфактум в (сверх)экономику дара» (Ямпольская, 2012: 8-9). 
Этот вывод следует понимать как прощение в совместном бытии - такой отсыл становится интригой предлагаемого Рикёром подхода. Философа интересует возможность применения противоречивой логики авраамической традиции безусловного прощения по отношению к персонифицированному субъекту, к людям в их совместной жизни. Для обоснования такой потенции он обращается к философии Х. Арендт.

\section{Прощение как категория теории действия X. Арендт}

Тема прощения раскрывается Арендт в контексте решения одной из основных задач её философии действия - утверждения дления и бессмертия человеческого мира через поступки и речь. Стремясь обосновать совместное бытие в качестве пространства бессмертия дел, Арендт выстраивает теорию действия во многом как ответ на экзистенциальную аналитику «Dasein» Хайдеггера. В противовес его идее конечности как предельном основании бытия Арендт утверждает принцип бессмертия в политической жизни, в жизни среди многих. Если Хайдеггер ищет смыслы бытия с позиции личностной экзистенции, то Арендт предлагает рассматривать плюральность (plurality) в качестве основного условия человеческой жизни 5 .

Стремясь обосновать возможность бессмертия в мире «хрупких человеческих дел», Арендт и ставит вопрос о прощении как об условии продления человеческой способности действовать. Прощение для нее - «спасительное средство против неотменимости содеянного» (Арендт, 2000: 313). «Если бы мы не могли прощать друг друга, взаимно освобождать от последствий того, что сделали, то наша способность действовать ограничилась бы одним деянием, от последствий которого мы никогда не могли бы оправиться» (Arendt, 1998: 237), - рассуждает Арендт в работе «Ситуация человека». Прощение одного поступка рассматривается ею как возможность осуществления новых действий в совместной жизни, как принцип освобождения от «травм прошлого» (Misztal, 2011: 50), «от последствий этого прошлого и того, кто прощает, и того, кому прощено» (Arendt, 1998: 241), и как разновидность действия с-другими-и-для-другого.

Прощение, по Арендт, - акт, зависимый от плюральности (plurality) человеческого бытия и реализующийся в совместной жизни. «Без окружающих нас людей мы не могли бы простить себе никакого недостатка или проступка», - заявляет она и продолжает, - «потому что нам не хватало бы опыта той личности, ради которой можно простить» (Arendt, 1998: 243). Что это за «личность», которой не хва-

5. Н. В. Мотрошилова отмечает: «Х. Арендт не просто берет как нечто данное и далее не исследуемое (как это делает ранний Хайдеггер) сферу Mit-dasein, бытия-вместе-с-другими, но обнаруживает в ней специфический, как раз бытийный обуславливающий слой, который каждый отдельный человек, рождающийся в этот мир, непременно застает „в наличии“, в его „da-“ (здесь, вот, тутсуществовании)» (Мотрошилова, 2013: 440). 
тает актору для прощения? С точки зрения Арендт, это его «кто», явленное перед другими на сцене «совместного» бытия.

«Кто» актора - образ, неоднократно появляющийся на страницах «Ситуации человека», связан с проблемой авторства смысла действия. Вопрос его идентификации Арендт решает также посредством категории плюральности. Она рассматривает совместное бытие актора с другими в качестве основного условия для формирования его «кто»: «Публичное выступление и дискурс с другими призывает самость отделиться от своего внутреннего мира» (Tchir, 2011: 55). В полной мере поступок индивида дан только другим: зрителям, рассказчикам о его действии и слушателям рассказов об этом действии. Такую определяющую роль других в вопрошании Арендт о «кто» отмечает и Рикёр: «...паутина человеческих отношений порождает процесс, из которого и может возникнуть уникальная история жизни каждого новоприходящего человека» (Ricoeur, 1983: 67).

Прощение рассматривается Арендт во многом в рамках продолжения разговора о «кто» актора, определяемого другими. В публичном пространстве другие, осуществляя акт прощения, оценивают прощаемого по его поступкам и создают образ его «кто»: «Именно поэтому я не могу простить себе сам: без других я не в состоянии установить отношение с кто меня самого» (Ямпольская, 2014: 20). «Только тот, кому уже простили, может простить сам себе» (Арендт, 200о: 315) вот принцип арендтовского прощения.

Наличие других как предпосылка прощения не только постулируется Арендт в терминах плюральности совместной жизни, но и рассматривается как условие отношений взаимности в сфере приватного, отношений Я-Другой. «Любящих отделяет от человеческого мира их безмирность, мир между любящими сгорел» (Арендт, 200о: 321), - пишет Арендт, рассматривая любовь в качестве одного из самых антиполитических явлений человеческой жизни.

В её теории прощение предстаёт двойственным феноменом, принадлежащим и пространству публичного, и области личного бытия, однако здесь нет противоречия, так как в основе двойственности лежит одно представление об авторе прощения.

Другой из сферы приватного и другие из пространства публичного как авторы прощения анализируются Арендт в контексте авраамической традиции представления о субъекте прощения. Актор прощения осмысляется ею по аналогии с божественным субъектом, дарующим прощение (Arendt, 1998: 238-239), а акт прощения - по аналогии с божественным чудотворением прощения. «Действие является способностью человека совершать чудеса - этот факт Иисус из Назарета... должен был хорошо знать, когда сравнивал силу прощать с силой чудотворения» (Arendt, 1998: 246-247).

Религиозный контекст приводит Арендт к отождествлению прощения с неким «чудом», событием - исключением из совместного бытия. В её теории прощение оказывается мимолётным поступком, разламывающим каузальную логику публичной жизни. С одной стороны, оно рассматривается как явление совместной 
жизни, с другой - как уникальный феномен, не свойственный принципам её организации (памяти, причинно-следственной связи поступков и речей), но необходимый для продолжения со-бытия друг с другом.

\section{Подходы Арендт и Рикёра к проблеме прощения: преемственность и различие}

Формулируя собственное представление о прощении, Рикёр то оспаривает, то всё же соглашается с Арендт и заимствует идеи её философии действия. Так, он берёт на «вооружение» темпоральный подход Арендт к прощению и вслед за ней предлагает анализировать прощение в качестве феномена, проясняющего временную структуру действия. Оба философа рассматривают прощение как темпоральный переход от прошлого действия к поступкам в настоящем и возможность для осуществления будущего акта. Рикёр соглашается и с принципом Арендт «прощать для того, чтобы действовать дальше». Прощение оказывается в их теориях условием продления способности действовать.

Тем не менее в целом Рикёра не устраивает событийный подход Арендт к прощению, её стремление анализировать прощение в терминах поступка. Он предлагает говорить о прощении «на том языке, на котором можно описать радикальную трансформацию самости (ipse) в её связи с самой собой и другими» (Ямпольская, 2015: 305).

Язык герменевтической феноменологии самости предполагает иное, чем у Арендт, отношение к роли других при определении прощаемого субъекта. С одной стороны, Рикёр соглашается с идеей Арендт, что прощение даёт возможность действовать не только тому, кого прощают, но и тем, кто прощает, развивая её мысль о том, что в основе способности прощать лежат опыты, «которые никто не может осуществлять в одиночестве» (Рикёр, 2004: 674). Однако другие не анализируются им в качестве авторов «кто» прощаемого.

На наш взгляд, Арендт и Рикёр задают вопросы о различных «кто»: для Арендт - это агент, образ которого формируется интерпретаторами его действия (Arendt, 1998: 179); для Рикёра «кто» «человека могущего» - это «Я-сам» (soimême) в диалектических отношениях с собой и с другими (Ricoeur, 1990: 28).

Отвечая на вопросы о «кто» homme capable, Рикёр придерживается персоналистского определения личности ${ }^{6}$, а также диалектики самости и инаковости, диалектики отношений Я-Другой-Другие. Он соглашается с Арендт в том, что человек «несёт в себе инстинктивное стремление к совместной с другими жизни» (Вдовина, 2013б: 269), но определяющим критерием «кто» всё же остаётся для него самосознание самости как говорящей, рассказывающей о себе: «Личность обозначает себя как „я“ по мере того, как говорящий субъект сам говорит о себе» (Вдови-

6. Рикёр переосмысливает персонализм Мунье, сохраняя понятие позиции и применяя его в собственной концепции «вовлечения»: «личность, считает он, является очагом позиции», «личность отождествляет себя с превосходящим ее делом» (Вдовина, 2013а: 156). 
на, 2013а: 161). По Рикёру, персонализация является задачей самого «кто». Другим же, на наш взгляд, он отдаёт функцию осознания этого «кто» как самодостаточного субъекта, обладающего способностью реализовать возможности говорения, действия, вменяемости.

В вопросе о прощении Рикёр остаётся верен собственному проекту герменевтической феноменологии самости и на его основе формулирует представление о субъекте, получаемом прощение. Он предлагает отличный от Арендт подход к «кто» виновного - не с позиции его определения как автора конкретного акта, а с позиции его осознания как самости, способной к действию вообще. Рикёр стремится анализировать прощение не в категориях поступка, как это делает Арендт, а в понятиях homme capable, что в результате приводит его к идее отделения агента от поступка.

\section{Проблема разделения агента и акта}

Отделить субъекта действия от его поступков - одна из основных задач концепции прощения Рикёра. Она ставится философом во многом в ответ на провозглашаемый в теориях Деррида, Гартмана принцип невозможности отделения виновного от его преступления. Если, например, Деррида под разделением виновного и его действия понимает прощение иного человека, а не того, кто совершил акт (Рикёр, 2004: 680), то Рикёр интерпретирует этот процесс как разъединение, совершаемое «в сердцевине возможности действия - agency, - иными словами, между осуществлением и возможностью» (Рикёр: 2004, 680). Актор понимается им не только как автор конкретного поступка, но и как субъект, потенциально обладающий способностью действовать.

К постановке задачи разъединения агента и его акта Рикёр приходит во многом благодаря переосмыслению концепции прощения Арендт, несмотря на различие их установок в вопросе о «кто». Он обнаруживает в её теории действия предпосылку для обоснования отделения агента от акта (Рикёр, 2004: 679) - принцип натальности (рождённости).

Многие комментаторы считают понятие натальности (natality) центральной категорией концепции действия Арендт (Kohn, 2000: 114), называют ее «теоретиком начинаний» (Arendt, 1998: vii). Данный термин она заимствует из философии Августина и применяет для описания человеческой способности начинать новое в процессе действия: «Посредством действия... каждый актуализирует собственный факт рождённости в качестве нового начала» (Taminiaux, 1986: 210). По Арендт, «...действие - это человеческий ответ на то, что удел человека - быть рождённым... без факта рождения мы бы даже не знали, что такое новизна, всякое действие было бы либо всего лишь поведением, либо консервированием» (Арендт, 2014: 96). При этом она трактует начинание действия не по аналогии с биологическим рождением, а как начало жизни в совместном бытии. «Говоря и действуя, мы включаемся в мир людей, существовавший прежде, чем мы в него родились, и это 
включение подобно второму рождению, когда мы подтверждаем голый факт нашей рождённости, словно берем на себя ответственность за него» (Арендт, 2ооо: 230).

Идея натальности оценивается Рикёром как одно из достижений теории действия Арендт (Bragantini, 2013: 147). Вопрошание к арендтовскому понятию натальности: «Каким образом связаны между собой господство над временем и чудо рождённости?» (Рикёр, 2004: 678-679) - даёт импульс всему предпринятому Рикёром обоснованию самости как духа прощения.

Философ перетолковывает идею натальности Арендт в контексте собственной герменевтики самости и принципа отделения актора от акта. Его проект прощения подразумевает виновного не столько как агента определённого проступка, сколько как самость, потенциально обладающую способностью обновления себя как человека могущего: «Виновный, способный начать всё с начала» (Рикёр, 2004: 680).

Задачу осознать возможность виновного на обновление Рикёр ставит не только перед самим виновным, но и перед теми другими, кто образует с ним совместное бытие и может выступить в роли авторов прощения. Он предлагает им проявить «доверие к возможностям возрождения „я“» (Рикёр, 2004: 680) виновного и даровать ему слово прощения: «Ты стоишь больше, чем твои действия» (Рикёр, 2004: 684-685).

Такое переоткрытие Рикёром смыслов арендтовского понятия натальности в контексте собственной философии самости становится основой решения загадки: возможно ли «прощение для нас»? С помощью переосмысления натальности он пытается перенести гимн прощения авраамической традиции с «высоты» абстрактного субъекта на «высоту» персонифицированных субъектов - участников совместного бытия, тех других, кто видит в виновном не только актора проступка, но и личность, способную на обновление.

Принцип натальности в интерпретации Рикёра наделяется функцией предпосылки возможного прощения, предстаёт аргументом, опровергающим позицию Деррида о прощении как об опыте невозможного. Натальность, понятая как возможность самости на обновление, утверждает прощение в качестве явления, присутствующего в совместном бытии постоянно. На наш взгляд, предполагаемая Рикёром константа прощения противоречит не только концепции Деррида, но и подходу Арендт к прощению как к событию-исключению, разламывающему каузальные отношения совместной жизни.

Предлагая собственный вариант понимания арендтовской идеи натальности, Рикёр в итоге занимает противоположную позицию как в вопросе о применении категории натальности, так и в вопросе о темпоральности прощения. Если Арендт рассматривает натальность как основание действия, не отделяя актора от поступка, то Рикёр предлагает применить натальность к личности актора. Если Арендт указывает на прощение как на «чудо» обновления совместной жизни, то Рикёр анализирует прощение как акт осознания постоянной возможности перерожде- 
ния личности. Он мыслит «прощение субъекта не в терминах точечного события, которое единожды разрывает внутреннее сознание времени субъекта и его личную историю, а в терминах сложного, „кругового“ процесса, который включает в себя всю его жизнь» (Ямпольская, 2015: 308).

Идея постоянного «кругового» прощения формулируется Рикёром в рамках этики дара и взаимности (Fiasse, 2007: 370). Философ предлагает говорить о прощении как о явлении дара с присущей ему диалектикой возврата: «Я прошу у тебя прощения - Я тебя прощаю» (Рикёр, 2004: 671). Подобный дискурс Рикёр, как и Деррида, обнаруживает в религиях Священного Писания, предполагающего безусловность прощения, но в то же время требующего и просьбу о нём (Рикёр, 2004: 780). Однако он не останавливается на абсолютизации данного противоречия и абсолютизации экономической структуры дара, а видит логику цикла в религиозной модели безусловности и просьбы прощения. Соединение прощения и раскаяния мыслится Рикёром в виде круга, «где экзистенциальный ответ на прощение некоторым образом включён в сам дар, в то время как то, что предшествует дару, признаётся находящимся в сердцевине изначального жеста покаяния» (Рикёр, 2004: 681).

Проект «прощения для нас» во многом и выстраивается Рикёром на основе этой традиционной религиозной модели круга «диалектики дара и взаимности». В его теории просьба о прощении оказывается знаком вменяемости ${ }^{7}$ виновного и основой для его уважения в пространстве совместного бытия. Принцип же уважения, который отражает переосмысление Рикёром арендтовской идеи натальности, определяется им как осознание возможности обновления действующего и вменяемого «кто» виновного. «Следовало бы вернуться к его способности действовать, к действию, имеющему продолжение» (Рикёр, 2004: 684).

В теории Рикёра уважение становится единственной возможной моделью «прощения для нас». Задаваясь вопросом о прощении в совместной жизни, он, в отличие от Арендт, обращает внимание не только на пространство политических дел, но и на институциональную жизнь в целом, в частности - на сферу судебной практики. Осознавая, «что в правовом отношении виновная самость не может быть прощена» (Рикёр, 2004: 679), он всё же в ответ на юридическую невозможность прощения выдвигает требование «инкогнито» прощения (Рикёр, 2004: 684685). Под этим тайньм прощением Рикёр и подразумевает уважение к виновному по причине того, что тот обладает возможностью обновления своей деятельной самости.

Тема уважения личности в сфере юриспруденции и права получает дополнительное раскрытие в сборнике эссе «Справедливое». В нём Рикёр указывает: «прощение служит постоянным напоминанием о том, что правосудие бывает лишь человеческим» (Рикёр, 2005: 169).

7. По Рикёру, вменяемость - это способность «действовать интенционально, то есть опираясь на разумные доводы, и инициативно вписывать свои намерения в ход вещей, в происходящие в мире события» (Ricoeur, 1992: 204). 


\section{«Прощение для нас»: диалектика памяти и забвения}

В поисках оснований «прощения для нас» Рикёр осознаёт проблематичность его реализации в сфере общественной жизни, в судебной практике, именует его «трудным актом», но возможным (Рикёр, 2004: 633). В теории же действия Арендт трудность прощения превращается подчас в невозможность. Понимая прощение как акт, исключительный для совместного бытия, Арендт накладывает на него дополнительные ограничения. Так, она считает, что существуют преступления, которые не поддаются ни прощению, ни наказанию (Arendt, 1998: 241). К ним в первую очередь относятся преступления против человечности. Об их акторах Арендт говорит словами Иисуса: «„Такому человеку было бы полезнее, если бы ему навесили жернов на шею и бросили в море“, или было бы лучше ему никогда не родиться - несомненно, самая страшная вещь, какую можно сказать о человеке» (Арендт, 200о: 320). Такое «проклятье» запрещает преступнику реализовать собственно человеческую природу, начать всё сначала. Постулируемый Арендт образ человека, способного к начинанию «нового», оказывается применимым не ко всем. В первую очередь она отказывает в возможности реализовать этот образ тем, кто в нацистских лагерях смерти пытался сделать людей «лишними человеческими существами» (Bernstein, 2006: 399).

Осмысляя трагедию Второй мировой войны, Арендт «заклинает» помнить об авторах преступлений против человечности. В лозунге её поздней политической теории: «где виноваты все, не виноват никто» (Arendt, 20о3а: 28) она выступает против применения к военным преступлениям принципа коллективной ответственности, потому что он предполагает забвение их акторов.

Арендт не употребляет слова «забвение», но её критика феномена коллективной ответственности опосредованно содержит в себе представление о забвении как о стирании следов. Рассуждая об ошибочности применения коллективной ответственности к послевоенной Германии, она указывает: «на практике это оказалось эффективным обелением (whitewash) всех тех, кто действительно что-либо совершил» (Arendt, 2003а: 21).

Снятие индивидуальной ответственности может привести к феномену «коллективного прощения», что также не устраивает Арендт (Pettigrove, 2006: 493-495). В своих философско-политических эссе она призывает к поиску ответственных за нацистские преступления и к их осуждению. Следя за судебными процессами послевоенных лет, Арендт формулирует концепцию суждения, главным героем которой становится «зритель» (Бейнер, 2011: 205), способный судить о преступлениях других в соответствии с собственной совестью. Каждый человек как представитель совместного бытия с другими обладает возможностью выносить суждение о чужих поступках, что и делает его собственно причастным к политическому. В частности, роли судящих зрителей в драме нацистских преступлений Арендт предлагает всем участникам современного мира. Она призывает к коллективному осуждению конкретных преступников и к их индивидуальной ответственности. 
В концепциях суждения и ответственности Арендт отрицается прощение в значении забвения авторства преступлений. Такие этико-моральные установки накладывают ограничения на представление Арендт о прощении как условии действия. Возьмём, например, Эйхмана. С одной стороны, Арендт описывает его как преступника, «банальные» злодеяния которого нужно помнить и судить (Arendt, 2003b: 16o). С другой стороны, она проповедует прощение как условие продления совместного бытия действий, что требует в каком-то смысле забыть о преступлениях Эйхмана и дать ему «шанс». Таким образом, принцип прощения, «обновлённый» идеями о непростительности, приводит к противоречию: не можем простить, потому что обязаны помнить, но должны прощать, чтобы действовать дальше в совместном бытии.

Подход Рикёра к «прощению для нас» как к «трудному» явлению совместной жизни не содержит подобного конфликта между памятью о злодеянии и его забвением. Он тоже упоминает о невозможности прощения преступлений против человечности (Рикёр, 2004: 650, 654-655), но не из-за невозможности забвения, а в связи с диалектикой памяти и забвения. По Рикёру, прощение - это феномен, находящийся на пересечении памяти и забвения. Основой прощения становится в его теории забвение-резерв, означающий «незаметный характер постоянного сохранения воспоминаний, уклонение от бдительного контроля сознания» (Рикёр, 2004: 609).

Забвение-резерв превращается в ресурс, «из которого черпает и на надёжность которого рассчитывает в своей деятельности «человек могущий» - главный персонаж рикёровской феноменологической герменевтики» (Блауберг, 2013: 206). Данный феномен Рикёр называет также «хорошим» забвением (ars oblivionis), paccматривая по аналогии с ним и прощение.

Определяя ars oblivionis и анализируя прощение, Рикёр применяет принцип меры памяти и забвения. Предлагая отделять виновного от его поступка, философ отождествляет прощение и с забвением как с освобождением от вчерашней и завтрашней злобы, и с памятью о том, что виновный обладает возможностью начать всё с начала. Рикёр приписывает прощению установку «хорошего забывания», а именно - «без-заботности» (Рикёр, 2004: 699). Прощение в его теории предполагает снятие оков заботы-памяти, постоянно пребывающей в прошлом. Оно оказывается «этическим применением забвения» (Dessingue, 2011: 175).

Таким образом, концепция прощения Рикёра, в отличие от теории Арендт, не отягощается противоречием между памятью и забвением. Если Арендт понимает прощение по аналогии с забвением, то Рикёр предлагает соединить работу памяти и забвения в акте прощения. Диалектика памяти и забвения даёт ему возможность непротиворечиво применять арендтовский принцип натальности в качестве условия возможности «прощения для нас». Формулируя понятие «инкогнито» прощения, Рикёр подразумевает под ним «хорошее забвение», освобождающее от скорби о прошлом, выводящее из озабоченности прошлым, но и учитывающее память уз- 
навания. «Вот он! Это он», - восклицает «хорошая память», она узнаёт виновного. A «хорошее забвение» дарует ему шанс на обновление, на «второе рождение».

В целом проект-поиск Рикёра «прощения для нас» предполагает константу прощения в качестве меры памяти и забвения. В нём место прощения как «опыта невозможного» занимает трудное, но постоянно возможное «инкогнито» прощения. В теории Рикёра константа прощения определяет историю совместной жизни и обосновывается не только цикличной моделью дара-раскаяния, но и идеей разделения актора и поступка, в основе которой лежит переосмысление арендтовского концепта натальности как источника постоянства возможности обновления самости виновного.

Для обоснования прощения в бытии «для нас» Рикёр во многом берёт на себя роль переоткрывателя идеи натальности Арендт, которая в своих представлениях о прощении остаётся сторонницей логики авраамо-христианского «чуда» прощения. С её точки зрения, прощение возможно в «сети межчеловеческих отношений», но только как событие-исключение, подобное божественному дару. При этом чудотворению прощения в её политической философии противоречит принцип памяти.

Концепции прощения Арендт и Рикёра разворачиваются в плоскости одних понятий: действие, возможность, обновление, совместное бытие, личность, память, забвение, но расходятся по своим внутренним принципам. Концепция прощения Арендт обладает апорийным содержанием: «чуду» прощения противоречит память, а концепция прощения Рикёра не содержит противоречия между памятью и забвением, между «чудом» и постоянством прощения. Если Арендт является сторонницей логики авраамо-христианского «чудотворения» прощения, то Рикёр критически применяет данный принцип. Его проект становится результатом критического подхода к теориям прощения, в которых присутствуют принципы авраамической традиции, в том числе - и к концепции Арендт.

Обращение к Арендт определяет интригу дискурса прощения в философии Рикёра. На наш взгляд, анализ данного обращения формирует новый подход к концепции прощения французского мыслителя - позволяет рассматривать её не только как теорию философии дара, не только как теорию - критику авраамического подхода, но и как проект-поиск возможного «прощения для нас».

Обнаружение в арендтовской идее натальности потенциала для решения вопроса «прощения для нас» делает концепцию Рикёра новаторской, придаёт ей формат дискуссии с идеей Деррида о «невозможном» прощении. Благодаря переосмыслению натальности Рикёр утверждает возможность прощения в сфере совместного бытия, раскрывает его участников как «видящих» в виновном не только актора проступка, но и личность, способную на обновление. 


\section{Литература}

Aрендm X. (200о). Vita activa, или О деятельной жизни / Пер. с англ. и нем. В. В. Бибихина. СПб.: Алетейя.

Арендm X. (2014). О насилии / Пер. с англ. Г. М. Дашевского. М.: Новое издательство.

Бейнер Р. (2011). Ханна Арендт о суждении // Арендт Х. Лекции по политической философии Канта / Пер. с англ. А. А. Глухова. СПб.: Наука. С. 147-255.

Блауберг И. И. (2013). О памяти и забвении: П. Рикёр и А. Бергсон // Поль Рикёр в Москве. М.: Канон+. С. 191-206.

Вдовина И. С. (2013а). Поль Рикёр: герменевтический подход к истории философии // Поль Рикёр в Москве. М.: Канон+. С. 152-19о.

Вдовина И. С. (2013б). Поль Рикёр: практическая мудрость философии // Поль Рикёр в Москве. М.: Канон+. С.267-276.

Мотрошилова Н. В. (2013). Мартин Хайдеггер и Ханна Арендт: бытие-времялюбовь. М.: Академический проект.

Рикёр П. (2004). Память, История, Забвение / Пер. с фр. И. И. Блауберг, И. С. Вдовиной, О. И. Мачульской, Г. М. Тавризян. М.: Издательство гуманитарной литературы.

Рикёр П. (2005). Справедливое / Пер. с фр. Б. Скуратова, П. Хицкого. М.: Гнозис, Логос.

Ямпольская А. В. (2012). Прощение между даром и обменом: антипелагианская полемика Августина в контексте философии века // Артикульт. № 7(3). С. 1-18.

Ямпольская A. В. (2014). Речевой акт как событие: Деррида между Остином и Арендт // Социологическое обозрение. Т. 13. № 2. С. 9-24.

Ямпольская А. В. (2015). За пределами события: Поль Рикёр о даре и прощении // Поль Рикёр: человек-общество-цивилизация. М.: Канон+. С. 302-314.

Arendt H. (1961). The Concept of History: ancient and modern // Arendt H. Between Past and Future. New York: The Viking Press. P. 41-90.

Arendt H. (1998). The Human Condition. Chicago: University of Chicago Press.

Arendt H. (2003a). Personal Responsibility Under Dictatorship // Arendt H. Responsibility and Judgment. New York: Schocken Books. P. 17-48.

Arendt H. (2003b). Thinking and Moral Considerations // Arendt H. Responsibility and Judgment. New York: Schocken Books. P. 159-192.

Bernstein R. J. (2006). Derrida: The Aporia of Forgiveness? // Constellations Vol. 13. № 3. P. 394-406.

Bragantini A. (2013). Identité personnelle et narration chez Paul Ricœur et Hannah Arendt // Lo Sguardo: rivista di filosofia. № 12 (II). P. 135-149.

Dessingué A. (2011). Towards a Phenomenology of Memory and Forgetting // Ricœur Studies Vol. 2. № 1. P. 168-178.

Derrida J. (1991). Donner le temps. 1. La fausse monnaie. Paris: Galilée.

Derrida J. (2005). On Cosmopolitanism and Forgiveness. London: Taylor \& Francis. 
Fiasse G. (2007). Paul Ricoeur et le pardon comme au-delà de l'action // Laval théologique et philosophique. Vol. 63. № 2. P. 363-376.

Kohn J. (2000). Freedom: The Priority of the Political // The Cambridge Companion to Hannah Arendt / Ed. D. Villa. New York: Cambridge University Press.

Misztal B. A. (2011). Forgiveness and the Construction of New Conditions for a Common Life // Contemporary Social Science. Vol. 6. № 1. P. 39-53.

Pettigrove G. (2006). Hannah Arendt and Collective Forgiving // Journal of Social Philosophy. Vol. 37. № 4. P. 483-500.

Ricoeur P. (1983). Action, Story and History: On Re-reading The Human Condition // Salmagundi. № 60. P. 60-72.

Ricoeur P. (1990). Soi-même comme un autre. Paris: Seuil.

Ricoeur P. (1992). Approches de la personne // Ricoeur P. Lectures 2. La contree des Philosophes. Paris: Seuil. P. 203-221.

Taminiaux J. (1986). Phenomenology and the Problem of Action // Philosophy Social Criticism. Vol. 11. P. 207-219.

Tchir T. (2011). Daimon Appearances and the Heideggerian Influence in Arendt's Account of Political Action // Action and Appearance: Ethics and the Politics of Writing in Hannah Arendt / Ed. C. Barbour and A. Yeatman. New York: Continuum. P. 53-68.

\title{
Forgiveness as a Possibility: The Approaches of H. Arendt and P. Ricoeur
}

\author{
Maria Sidorova \\ Postgraduate Student, School of Philosophy, National Research University Higher School of Economics \\ Address: Myasnitskaya str., 20, Moscow, Russian Federation 101000 \\ E-mail:msi.8883@gmail.com
}

The theme of forgiveness unites H. Arendt's and P. Ricoeur's different philosophical interests. Both thinkers analyze this phenomenon in the context of the Avraama-Christian tradition of forgiveness, and ask the question concerning the opportunity of forgiveness in common life. This article gives the reasons for Ricoeur's references to Arendt's concept of forgiveness. It puts forward the idea that the rethinking of natality is a basis of Ricoeur's concept of "forgiveness for us". This article describes both the continuity and disagreement in Ricoeur's and Arendt's approaches to the issue of forgiveness. If Arendt conceptualizes forgiveness in terms of act, Ricoeur examines this phenomenon from the perspective of selfhood. For Arendt, forgiveness is not a typical action, but an event breaking the causal structure of common being. For her, forgiveness is some exception from the public space necessary for its own existence. Ricoeur proposes to consider forgiveness as a constant of common being. He analyzes forgiveness as a difficult act, but always possible "incognito". Despite these differences, Arendt's notion of natality becomes the decisive category for Ricoeur in justifying the constant of forgiveness. In introducing the condition of the separation between agent and act, he recognizes natality as a cause of the possible update of a guilty selfhood. This article assumes that Ricoeur's appeal to Arendt helps him to formulate his own concept of forgiveness based on the review of the principles of the Avraamic tradition and its 
reception in Derrida's philosophy. Thanks to Arendt, the place of forgiveness in Ricoeur's theory as an "experience of the impossible" takes the difficult , but always possible, "incognito" forgiveness.

Keywords: forgiveness, action, memory, forgetting, plurality, natality, Ricoeur, Arendt

\section{References}

Arendt H. (2000) Vita activa, ili O deyatelnoj zhizni [Vita Activa; or, On Active Life], Saint Petersburg: Aleteja.

Arendt H. (2014) O nasilii [On Violence], Moscow: Novoe izdatelstvo.

Beiner R. (2011) Hanna Arendt o suzhdenii [Hannah Arendt about judgment]. Arendt H. Lekcii po politicheskoj filosofii Kanta [Lectures on Kant's political philosophy], Saint Petersburg: Nauka, pp. 147- 255.

Blauberg I. (2013) O pamyati i zabvenii: P. Ricoeur i A. Bergson [On Memory and Forgetting: P. Ricoeur and A. Bergson]. Paul Ricoeur v Moskve [Paul Ricoeur in Moscow], Moscow: Kanon+, pp. 191-206.

Vdovina I. (2013a) Paull Ricoeur: germenevticheskij podhod k istorii filosofii [Paul Ricoeur: Hermeneutic Approach to the History of Philosophy]. Paul Ricoeur v Moskve [Paul Ricoeur in Moscow], Moscow: Kanon+, pp. 152-190.

Vdovina I.S. (2013b) Pol Ricoeur: practicheskaya mudrost filosofii [Paul Ricoeur; practice wisdom]. Paul Ricoeur v Moskve [Paul Ricoeur in Moscow], Moscow: Kanon+, pp. 267-276.

Motroshilova N. (2013) Martin Haidegger i Hanna Arendt: butie-vremya-lyubov [Martin Haidegger and Hannah Arendt: Being-Time-Love], Moscow: Akademicheskij proekt.

Ricoeur P. (2004) Pamyat, Istoria, Zabvenie [Memory, History, Forgetting], Moscow: Izdatelstvo gumanitarnoj literatury.

Ricoeur P. (2005) Spravedlivoe [Just], Moscow: Gnozis<> Logos.

Yampolskaya A. (2012) Prosshenie mezhdu darom i obmenom: antipelagianskaya polemika Avgustina v kontekste filosofii veka [Forgiveness Between Gift and Exchange: Antipelagic Controversy of Augustine in the Context of the Philosophy of the Century]. Articult, no 7(3), pp. 1-18.

Yampolskaya A. (2014) Rechevoi akt kak sobutie: Derrida mezhdu Ostinom i Arendt [Speech Act as an Event: Derrida Between Austin and Arendt]. Russian Sociological Review, vol. 13, no 2, pp. 9-24.

Yampolskaya A. (2015) Za predelami sobutia: Paul Ricoeur o dare i prosshenii [Outside of an Event: Paul Ricoeur on the Gift and Forgiveness]. Paul Ricoeur v Moskve [Paul Ricoeur in Moscow], Moscow: Kanon+, pp. 302-314.

Arendt H. (1961) The Concept of History: Ancient and Modern. Between Past and Future, New York: The Viking Press, pp. 41-90.

Arendt H. (1998) The Human Condition, Chicago: University of Chicago Press.

Arendt H. (2003a) Personal Responsibility Under Dictatorship. Responsibility and Judgment, New York: Schocken Books, pp. 17-48.

Arendt H. (2003b) Thinking and Moral Considerations. Responsibility and Judgment, New York: Schocken Book, pp. 159-192.

Bernstein R. J. (2006) Derrida: The Aporia of Forgiveness? Constellations, vol. 13, no 3, pp. 394-406.

Bragantini A. (2013) Identité personnelle et narration chez Paul Ricœur et Hannah Arendt. Lo Sguardo: rivista di filosofia, no 12 (II), pp. 135-149.

Dessingué A. (2011) Towards a Phenomenology of Memory and Forgetting. Ricœur Studies, vol. 2, no 1, pp. 168-178.

Derrida J. (1991) Donner le temps 1: La fausse monnaie, Paris: Galilée.

Derrida J. (2005) On Cosmopolitanism and Forgiveness, London: Taylor \& Francis.

Fiasse G. (2007) Paul Ricoeur et le pardon comme au-delà de l'action. Laval théologique et philosophique, vol. 63, no 2, pp. 363-376.

Kohn J. (2000) Freedom: The Priority of the Political. The Cambridge Companion to Hannah Arendt (ed. D. Villa), New York: Cambridge University Press.

Misztal B. A. (2011) Forgiveness and the Construction of New Conditions for a Common Life. Contemporary Social Science, vol. 6, no 1, pp. 39-53. 
Pettigrove G. (2006) Hannah Arendt and Collective Forgiving. Journal of Social Philosophy, vol. 37, no 4, pp. 483-500.

Ricoeur P. (1983) Action, Story and History: On Re-reading the Human Condition. Salmagundi, no 60, pp. 60-72.

Ricoeur P. (1990) Soi-même comme un autre, Paris: Seuil.

Ricoeur P. (1992) Approches de la personne. Lectures 2: La contree des Philosophes, Paris: Seuil, pp. 203-221.

Taminiaux J. (1986) Phenomenology and the Problem of Action. Philosophy Social Criticism, vol. 11, pp. 207-219.

Tchir T. (2011) Daimon Appearances and the Heideggerian Influence in Arendt's Account of Political Action. Action and Appearance: Ethics and the Politics of Writing in Hannah Arendt (eds. C. Barbour, A. Yeatman), New York: Continuum, pp. 53-68. 